\title{
WILLIAM MARTIN MUIRHEAD
}

William Martin Muirhead died quietly in his sleep on March 4, 1952; he died, as he would have wished, in harness. It is clear now that he had been anything

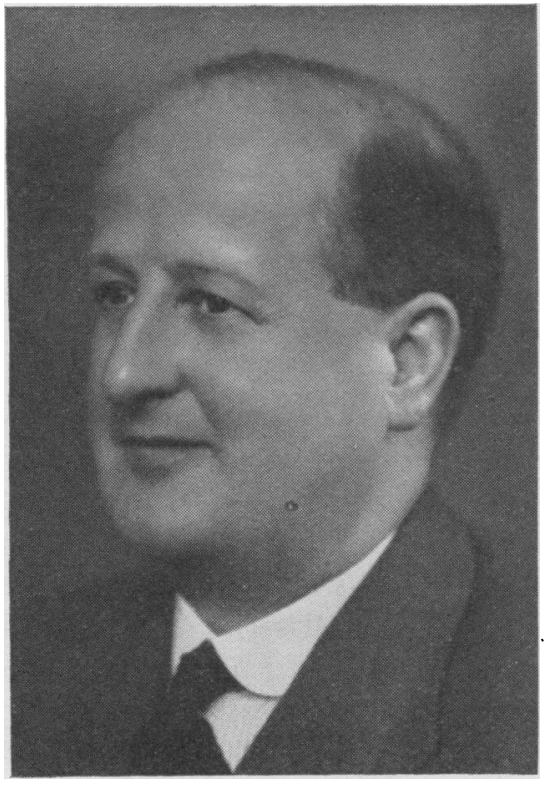

WILLIAM MARTIN MUIRHEAD but fit for some months, but, characteristically, his reaction was that it would pass off and that anyhow it was much better to " keep cracking".

Born in Sheffield and educated at Wesley College and Sheffield University, he graduated M.B., Ch.B. in 1911. He held a resident post at the Sheffield Royal Hospital in the Ophthalmic Department which, to-day, would be classed as a Registrarship. He served in the R.A.M.C. from 1916 to 1921, and for a good deal of that time was working as an eye specialist. On leaving the Army he turned seriously to the task of equipping himself as an ophthalmologist, and, being the meticulous person he was, decided to start at the beginning. $\mathrm{He}$ held Out-Patient and Resident posts at Moorfields, and there is no doubt that these were among the happiest days of his life. Of this period Maurice Whiting writes:

When W. M. Muirhead came to Moorfields as House Surgeon in 1924 after a period of war service followed by two years in London Hospitals, he was older and a good deal more experienced than the average House Surgeon of those days. This might have made him feel the junior position a rather difficult one, but there was never any sign of this. He worked with both his senior and junior colleagues with the greatest sense of equality and friendliness. I think all the consultant staff found him an excellent House Surgeon as well as a delightful man to work with, and everyone missed him when he left to take up a consultant appointment.

He had a great charm of manner and this was not superficial polish, for that was alien to his nature, but rather the result of a genuine friendliness shining through. At the same time he did not conceal his views even when unfavourable in any way, and this was a most satisfactory feature in discussions on matters professional, political, or social. His hearers had no doubt of the nature of his opinion and this element of frankness was an important and attractive part of his character. Many of us have kept up our early acquaintance through the passing years and our appreciation of his qualities both professional and personal increased with time.

My latest memory of him is of last year's visit to Belgium and Northern France, when he conducted the party with his usual efficiency, geniality, and delightful comradeship. All who were there will cherish this recollection.

He took the D.O.M.S. of the Royal Colleges in 1927 and shortly afterwards was appointed Honorary Ophthalmic Surgeon to the Chesterfield and North Derbyshire 
Royal Hospital, and oculist to the Chesterfield Education Committee. In 1939 he was appointed Honorary Ophthalmic Surgeon to the Rotherham and Worksop hospitals. The immense amount of work resulting from these extra appointments was made possible only by his partnership with his brother, "H. C.", which began about that time. It was a remarkable partnership, founded on a deep mutual affection, and resulted in an efficient and much appreciated service.

On the death of Percival Hay in 1943, he was selected as Secretary of the North of England Ophthalmological Society, and in this responsible task his amazing capacity for hard work and attention to detail found their proper scope. It would be correct to say that this was the activity nearest his heart; in managing its affairs he was remarkably successful in preserving harmony and maintaining a proper balance between the scientific, the political, and the social.

All scientific meetings were a joy to him, not only on account of the interesting and rare cases which he appreciated so much, but also because such meetings helped to bring ophthalmologists together and promote the goodwill which, in his view, was the basis of progress and good work. His many activities in connection with ophthalmology show how seriously he took his life's work.

It was with tremendous zest and happiness that he led Faculty Study Tours abroad, and on these tours the real "Bill", as he was affectionately known to his friends, came to life, and one realized to the full his modesty and kindly hospitable nature. Of such a man it may be truly said that he lived respected and died regretted. Many, at home and abroad, have lost a personal friend, and ophthalmology an influence for harmony and progress difficult to assess.

\section{A. B. NutT}

W. M. Muirhead could be deeply moved by the simple attempts of humble, practical men to better themselves in any walk of life, and would become very indignant indeed if he suspected that any of his protégés was not being given a square deal. He had the greatest admiration for men who did things, as opposed to those who derived their knowledge second-hand from books and theory.

His career was profoundly influenced by the exceptionably able group of ophthalmologists, mainly Scottish, whom he met in Salonika during the first world war. Anderson, Ballantyne, Sinclair, Edgar Smith, and, above all, Usher, were frequently quoted as exemplars to be followed in all things, both social and technical. It was from these men that he realized, more fully than he had done before, the need for a basic training built upon genuine observation and personal experience; and so it came about that in the early 1920 s he came back to the study of anatomy and physiology although by that time he was over thirty years old.

There is an old proverb-“"Knowledge directeth practice: but yet practice increaseth knowledge "- which aptly summarizes his outlook upon his work. The detailed and painstaking establishment of negative findings gave him great satisfaction, but added many hours to the routine work of the day. The older generation of staff and residents at Moorfields will recall the meticulous care with which his records were kept. This approach stemmed back quite clearly to his contacts with Usher and the tradition of the great Victorian clinical observers.

W. J. B. RIDDELI 